\title{
Asuhan Keperawatan Jiwa Dengan Masalah Kecemasan Pada Penderita Hipertensi: Studi Kasus
}

\author{
Mary Lowrenza Samosir
}

\author{
marylowrenza28@gmail.com
}

\section{BAB 1}

\section{PENDAHULUAN}

\subsection{LatarBelakang}

Hipertensi merupakan salah satu penyakit kardiovaskuler yang paling umum dan paling banyak disandang masyarakat. Hipertensi sekarang jadi masalah utama kita semua, tidak hanya di Indonesia tapi di dunia, karena hipertensi merupakan salah satu pintu masuk atau faktor risiko penyakit seperti jantung, gagal ginjal, diabetes dan stroke (Kemenkes RI, 2019). Berdasarkan data World Health Organization (WHO), prevalensi tekanan darah tinggi tahun 2014 pada orang dewasa berusia 18 tahun keatas sekitar $22 \%$. Penyakit ini juga menyebabkan $40 \%$ kematian akibat penyakit jantung dan $51 \%$ kematian akibat stroke. Selain secara global, hipertensi juga menjadi salah satu penyakit tidak menular yang paling banyak diderita masyarakat Indonesia (57,6\%), di dalam (Jumriani, 2019). Riset Kesehatan Dasar (Riskesdas) yang dilakukan Kementerian Kesehatan tahun 2018 menghasilkan peningkatan kejadian hipertensi dibandingkan hasil pada tahun 2013. Pravalensi kejadian hipertensi berdasarkan hasil riskesdas 2018 adalah 34,1\%. Angka tersebut lebih tinggi dibandingkan tahun 2013 yang menyentuh angka pravalensi $25,8 \%$.

Secara nasional hasil Riskesdas 2018 menunjukkan bahwa prevalensi penduduk dengan tekanan darah tinggi sebesar 34,11\%. Prevalensi tekanan darah tinggi pada perempuan $(36,85 \%)$ lebih tinggi dibanding dengan lakilaki (31,34\%). Prevalensi di perkotaan sedikit lebih tinggi $(34,43 \%)$ 
dibandingkan dengan perdesaan $(33,72 \%)$. Prevalensi semakin meningkat seiring dengan pertambahan umur (Kemenkes RI, 2019).

Hasil tersebut merupakan kejadian hipertensi berdasarkan hasil pengukuran tekanan darah pada masyarakat Indonesia berusia 18 tahun ke atas (Kementerian Kesehatan RI, 2018). Angka pravalensi hipertensi di Indonesia sebesar 63.309.620 orang atau berkisar antara 6-15\% dan telah banyak dikumpulkan yang menunjukkan didaerah pedesaan masih banyak penderita yang belum terjangkau oleh pelayanan kesehatan. Kecemasan merupakan suatu respon psikologis maupun fisiologis individu terhadap suatu keadaan yang tidak menyenangkan, atau reaksi atas situasi yang dianggap mengancam (Hulu \& Pardede, 2016).

Kecemasan merupakan perasaan ketakutan yang tidak memiliki penyebab yang jelas dan tidak didukung oleh situasi, kecemasan dapat dirasakan oleh setiap orang jika mengalami tekanan dan perasaan yang mendalam menyebabkan masalah kejiwaan dan berkembangan dalam jangka panjang (Pardede, Simanjuntak \& Manulu, 2020). Sedangkan menurut (Sitepu \& Simanungkalit, 2019). Kecemasan keadaan ketika emosi negative muncul akibat kekhawatiran akan bahaya yang tidak terduga yang mungkin terjadi di masa depan. Kecemasan sebenarnya adalah perasaan yang normal dimiliki oleh manusia, karena saat cemas manusia disadarkan dan diingatkan tentang bahaya yang mengancam dirinya.

Kondisi hipertensi akan semakin memburuk bila pasien mengalami ansietas. Tanda dan gejala pasien ansietas terdiri dari dua komponen yaitu psikis dan fisik. Tanda dan gejala psikis yaitu mengalami peningkatan tekanan darah, khawatir, was - was, apabila fisik yaitu tangan dan kaki merasa dingin dan ketegangan otot, nafas semakin cepat, jantung berdebar, mulut kering, keluhan lambung itu terjadi karena adanya peningkatan adrenalin kondisi ini akan membahayakan pasien hipertensi (Nurma, 2019). Kecemasan yang terjadi tidak saja dialami oleh seorang pasien tetapi dapat juga dialami oleh 
keluarga yang anggota keluarganya dirawat di rumah sakit sehingga diperlukan mekanisme koping keluarga yang dapat membantu keluarga dalam menghadapi masalah kecemasan (Sentana 2016, dalam Pardede, 2020).

Kecemasan (ansietas) ini dapat diatasi dengan beberapa cara, antara lain terapi farmakologi dan terapi non farmakologi. Terapi farmakologi seperti obat anti cemas (anxiolytic) dapat membantu menurunkan cemas tetapi memiliki efek ketergantungan, sedangkan terapi non farmakologi seperti psikoterapi, terapi tertawa, terapi kognitif, relaksasi dan salah satunya dengan hipnotis lima jari (Marbun, 2019). Kecemasan juga dapat di atasi dengan teknik relaksasi, distraksi, kegiatan spiritual, dan hipnoterapi. Upaya yang dilakukan untuk mengatasi stres dan kecemasan yaitu dengan menggunakan teknik relaksasi karena di anggap sebagai relaksasi termudah (Alivian, 2019).

Metode lain dalam menangani kecemasan yaitu dengan mendekatkan diri kepada Tuhan dengan mendengarkan dan mengucapkan doa dalam hati secara bersungguh-sungguh. Doa merupakan suatu media penyembuh yang dapat menimbulkan ketenangan, motivasi positif, kepasrahan, rasa optimis dan semangat hidup, sehingga sesuai dengan teori penanganan kecemasan yaitu meningkatkan adaptasiterhadap stres danterapi psikoreligius (Alivian, 2019).

\subsection{RumusanMasalah}

Berdasarkan latar belakang masalah tersebut maka dapat dirumuskan sebagai berikut maka dapat di rumuskan sebagai berikut" Bagaimana penerapan asuhan keperawatan pada Tn. A dengan masalah kecemasan di Wilayah Desa Penggalangan Kecamatan Tebing Syahbandar. 


\subsection{Tujuan penulisan}

\subsubsection{Tujuan Umum}

Mahasiswa mampu memberikan asuhan keperawatan kepada Tn. A dengan diagnosa kecemasan

\subsubsection{Tujuan khusus}

1. Mahasiswa mampu melakukan pengkajian pada Tn. A dengan diagnosa kecemasan.

2. Mahasiswa mampu menegakkan diagnosa keperawatan yang ada pada Tn. A dengan diagnosa kecemasan.

3. Mahasiswa mampu menetapkan perencanaan keperawatan pada Tn. A dengan diagnosa kecemasan.

4. Mahasiswa mampu melakukan implementasi keperawatan pada Tn. A dengan diagnosa kecemasan.

5. Mahasiswa mampu mengevaluasi hasil asuhan keperawatan pada Tn.A dengan diagnosa kecemasan.

6. Mendokumentasikan asuhan keperawatan yang diberikan pada Tn.A dengan diagnosa kecemasan. 


\section{BAB 2}

\section{TINJAUAN TEORITIS}

\subsection{Konsep Hipertensi}

\subsubsection{Pengertian}

Hipertensi atau tekanan darah tinggi adalah suatu keadaan dimana tekanan darah sistolik $\geq 140 \mathrm{mmHg}$ dan atau tekanan darah diastolik $\geq$ $90 \mathrm{mmHg}$. Umumnya, seseorang dikatakan mengalami hipertensi jika tekanan darah berada di atas 140/90 mmHg. Hipertensi dibedakan menjadi dua macam, yakni hipertensi primer (esensial) dan hipertensi sekunder. Penyebab tingginya angka penderita hipertensi di Indonesia adalah dengan adanya perubahan life style dengan mengkomsusmsi makanan yang tinggi kadar kolestrol, makanan yang kandungan garam yang tinggi, kurangnya berolah raga dan tidak terlepas dari faktor genetik (Nade \& Rantung, 2020).

\subsubsection{Etiologi}

Berdasarkan penyebab hipertensi pada usia lanjut dibagi menjadi dua golongan :

1. Hipertensi essensial (hipertensi primer) :

Hipertensi primer adalah hipertensi esensial atau hiperetnsi yang 90\% tidak diketahui penyebabnya. Beberapa faktor yang diduga berkaitan dengan berkembangnya hipertensi esensial diantaranya, (Yulianto, 2016) :

a. Genetika

Individu dengan keluarga hipertensi memiliki potensi lebih tinggi mendapatkan penyakit hipertensi.

b. Jenis Kelamin Dan Usia

Lelaki berusia 35-50 tahun dan wanita yang telah menopause berisiko tinggi mengalami penyakit hipertensi.

c. Diit Konsumsi Tinggi Garam Atau Kandungan Lemak 
d. Konsumsi garam yang tinggi atau konsumsi makanan dengan kandungan lemak yang tinggi secara langsung berkaitan dengan berkembangnya penyakit hipertensi.

e. Berat Badan Obesitas

Berat badan yang 25\% melebihi berat badan ideal sering dikaitkan dengan berkembangnya hipertensi.

f. Gaya Hidup Merokok Dan Konsumsi Alcohol

Merokok dan konsumsi alkohol sering dikaitkan dengan berkembangnya hipertensi karena reaksi bahan atau zat yang terkandung dalam keduanya.

\section{Hipertensi Sekunder}

Hipertensi sekunder adalah jenis hipertensi yang diketahui penyebabnya. Menurut (Ratnawati, 2017), Hipertensi sekunder disebabkan oleh beberapa penyakit, yaitu :

a. Coarctation aorta, yaitu penyempitan aorta congenital yang mungkin terjadi beberapa tingkat pada aorta toraksi atau aorta abdominal. Penyembitan pada aorta tersebut dapat menghambat aliran darah sehingga terjadi peningkatan tekanan darah diatas area kontriksi.

b. Penyakit parenkim dan vaskular ginjal. Penyakit ini merupakan penyakit utama penyebab hipertensi sekunder. Hipertensi renovaskuler berhubungan dengan penyempitan

c. Satu atau lebih arteri besar, yang secara langsung membawa darah ke ginjal. Sekitar $90 \%$ lesi arteri renal pada pasien dengan hipertensi disebabkan oleh aterosklerosis atau fibrous dyplasia (pertumbuhan abnormal jaringan fibrous). Penyakit parenkim ginjal terkait dengan infeksi, inflamasi, serta perubahan struktur serta fungsi ginjal.

d. Penggunanaan kontrasepsi hormonal (esterogen). Kontrasepsi secara oral yang memiliki kandungan esterogen dapat menyebab kan terjadinya hipertensi melalui mekanisme reninaldosteron-mediate volume expantion. Pada hipertensi ini, 
tekanan darah akan kembali normal setelah beberapa bulan penghentian oral kontrasepsi.

e. Gangguan endokrin. Disfungsi medulla adrenal atau korteks adrenal dapat menyebabkan hipertensi sekunder. Adrenalmediate hypertension disebabkan kelebihan primer aldosteron, kortisol, dan katekolamin.

f. Stress, yang cenderung menyebabkan peningkatan tekanan darah untuk sementara waktu.

g. Kehamilan

h. Luka bakar

i. Peningkatan tekanan vaskuler

j. Merokok : Nikotin dalam rokok merangsang pelepasan katekolamin. Peningkatan katekolamin mengakibatkan iritabilitas miokardial, peningkatan denyut jantung serta menyebabkan vasokortison yang kemudian menyebabkan kenaikan tekanan darah.

\subsubsection{Klasifikasi Hipertensi}

Menurut World Health Organization (dalam Noorhidayah, S.A. 2016). klasifikasi hipertensi adalah :

1. Tekanan darah normal yaitu bila sistolik kurang atau sama dengan140 mmHg dan diastolic kurang atau sama dengan $90 \mathrm{mmHg}$.

2. Tekanan darah perbatasan (borderline) yaitu bila sistolik 141-149 $\mathrm{mmHg}$ dan diastolik 91-94 mmHg.

3. Tekanan darah tinggi (hipertensi) yaitu bila sistolik lebih besar atau sama dengan $160 \mathrm{mmHg}$ dan diastolic lebih besar atau sama dengan $95 \mathrm{mmHg}$.

Menurut Tambayong (dalam Nurarif A.H \& Kusuma H. 2016), klasifikasi hipertensi klinis berdasarkan tekanan darah sistolik dan diastolic yaitu : 


\begin{tabular}{|c|l|c|c|}
\hline No & \multicolumn{1}{|c|}{ Kategori } & $\begin{array}{c}\text { Sistolik } \\
(\mathbf{m m H g})\end{array}$ & $\begin{array}{c}\text { Diastolik } \\
(\mathbf{m m H g})\end{array}$ \\
\hline 1. & Optimal & $<120$ & $<80$ \\
\hline 2. & Normal & $120-129$ & $80-90$ \\
\hline 3. & High Normal & $130-139$ & $80-84$ \\
\hline 4. & Hipertensi & $140-159$ & $90-99$ \\
\hline 5. & Grade 1 (ringan) & $160-179$ & $100-109$ \\
\hline 6. & Grade 2 (sedang) & $180-209$ & $100-119$ \\
\hline 7. & Grade 3 (berat) & $>210$ & $>210$ \\
\hline 8. & Grade 4 (sangat berat) & \multicolumn{2}{c|}{} \\
\hline
\end{tabular}

\subsubsection{Komplikasi}

Komplikasi yang di timbulkan akibat hipertensi adalah :

1. Penyakit arteri coroner

Penyakit ini mengacu pada terjadinya penyumbatan di pembuluh darah yang mensuplai nutrisi dan oksigen ke jantung. Sumbatan ini umumnya terjadi akibat adanya penumpukan lemak dan sel-sel yang di sebut makfrog, sumbatan yang terjadi pada arteri koroner merupakan penyebab utama pada serangan jantung (Yulia, 2018).

\subsection{Konsep Kecemasan}

\subsubsection{Pengertian}

Kecemasan adalah suatu perasaan khawatir yang berlebihan dan tidak jelas, juga merupakan suatu respons terhadap stimuli eksternal maupun internal yang menimbulkan gejala emosional, kognitif, fisik, dan tingkah laku. Ketika merasa cemas, individu merasa tidak nyaman atau takut atau mungkin memiliki firasat akan ditimpa malapetaka padahal ia tidak mengerti mengapa emosi yang mengancam tersebut terjadi. Kecemasan dapat dilihat dalam rentang ringan, sedang, berat sampai panik. Setiap tingkat menyebabkan perubahan fisiologis dan emosional pada individu (Wati, 2017). Kecemasan merupakan suatu keadaan perasaan gelisah, ketidaktentuan, ada rasa takut dari kenyataan atau persepsi ancaman sumber aktual yang tidak diketahui masalahnya (Pardede \& Simangunsong, 2020). 


\subsubsection{Etiologi}

Etiologi Gangguan Kecemasan Terdiri Dari :

1. Faktor Predisposisi

Stressor predisposisi adalah semua ketegangan dalam kehidupan yang dapat menyebabkan timbulnya kecemasan (Stuart, Keliat \& Pasaribu, 2016). Ketegangan dalam kehidupan tersebut dapat berupa :

a. Peristiwa Traumatik, yang dapat memicu terjadinya kecemasan berkaitan dengan krisis yang dialami individu baik krisis perkembangan atau situasional.

b. Konflik Emosional, yang dialami individu dan tidak terselesaikan dengan baik. Konflik antara individu dan super ego atau antara keinginan dan kenyataan dapat menimbulkan kecemasan pada individu.

c. Konsep diri terganggu akan menimbulkan ketidakmampuan individu berpikir secara realitas sehingga akan menimbulkan kecemasan.

d. Frustasi akan menimbulkan rasa ketidakberdayaan untuk mengambil keputusan yang berdampak terhadap ego.

e. Gangguan fisik akan menimbulkan kecemasan karena merupakan ancaman terhadap integritas fisik yang dapat mempengaruhi konsep diri individu.

f. Pola mekanisme koping keluarga atau pola keluarga menangani stress akan mempengaruhi individu dalam berespon terhadap konflik yang dialami karena pola mekanisme koping individu banyak dipelajari dalamkeluarga.

g. Riwayat gangguan kecemasan dalam keluarga akan mempengaruhi respons individu dalam berespons terhadap konflik dan mengatasi kecemasannya.

h. Medikasi yang dapat memicu terjadinya kecemasan adalah pengobatan yang mengandung benzodiazepin, karena benzodiazepine dapat menekan neurotransmiter gamma amino 
butyric acid (GABA) yang mengontrol aktivitas neuron di otak yang bertanggung jawab menghasilkan kecemasan.

\section{Faktor presipitasi}

Stresor presipitasi adalah semua ketegangan dalam kehidupan yang dapat mencetuskan timbulnya kecemasan (Stuart, Keliat \& Pasaribu, 2016). Stressor presipitasi kecemasan dikelompokkan menjadi dua bagian, yaitu :

a. Ancaman terhadap integritas fisik. Ketegangan yang mengancam integritas fisik yang meliputi:

1) Sumber Internal, meliputi kegagalan mekanisme fisiologis sistem imun, regulasi suhu tubuh, perubahan biologis normal (misalnya : hamil).

2) Sumber Eksternal, meliputi paparan terhadap infeksi virus dan bakteri, polutan lingkungan, kecelakaan, kekurangan nutrisi, tidak adekuatnya tempat tinggal.

b. Ancaman terhadap harga diri meliputi sumber internal dan eksternal:

1) Sumber Internal : kesulitan dalam berhubungan interpersonal di rumah dan tempat kerja, penyesuaian terhadap peran baru. Berbagai ancaman terhadap integritas fisik juga dapat mengancam harga diri.

2) Sumber Eksternal : kehilangan orang yang dicintai, perceraian, perubahan status pekerjaan, tekanan kelompok, sosial budaya.

3. Faktor-Faktor Yang Mempengaruhi Kecemasan

Terdapat dua faktor yang dapat menimbulkan kecemasan, yaitu.

a. Pengalaman negatif pada masa lalu Sebab utama dari timbulnya rasa cemas kembali pada masa kanak-kanak, yaitu timbulnya rasa tidak menyenangkan mengenai peristiwa yang dapat terulang lagi pada masa mendatang, apabila individu menghadapi situasi yang sama dan juga menimbulkan 
ketidaknyamanan, seperti pengalaman pernah gagal dalam mengikuti tes.

b. Pikiran yang tidak rasional Pikiran yang tidak rasional terbagi dalam empat bentuk, yaitu :

1) Kegagalan ketastropik, yaitu adanya asumsi dari individu bahwa sesuatu yang buruk akan terjadi pada dirinya. Individu mengalami kecemasan serta perasaan ketidakmampuan dan ketidaksanggupan dalam mengatasi permasalahannya.

2) Kesempurnaan, individu mengharapkan kepada dirinya untuk berperilaku sempurna dan tidak memiliki cacat. Individu menjadikan ukuran kesempurnaan sebagai sebuah target dan sumber yang dapat memberikan inspirasi.

3) Persetujuan

4) Generalisasi yang tidak tepat, yaitu generalisasi yang berlebihan, ini terjadi pada orang yang memiliki sedikit pengalaman

\subsubsection{TingkatKecemasan}

Menurut Ii (2021), Tingkatan kecemasan terbagi atas empat, yaitu :

1. Kecemasan Ringan

Kecemasan ini berhubungan dengan kehidupan sehari-hari. Kecemasan ini dapat memotivasi belajar menghasilkan pertumbuhan serta kreatifitas. Tanda dan gejala antara lain: persepsi dan perhatian meningkat, waspada, sadar akan stimulus internal dan eksternal, mampu mengatasi masalah secara efektif serta terjadi kemampuan belajar. Perubahan fisiologi ditandai dengan gelisah, sulit tidur, hipersensitif terhadap suara, tanda vital dan pupil normal.

2. Kecemasan Sedang

Kecemasan sedang memungkinkan seseorang memusatkan pada hal yang penting dan mengesampingkan yang lain, sehingga 
individu mengalami perhatian yang selektif, namun dapat melakukan sesuatu yang lebih terarah. Respon fisiologi: sering nafas pendek, nadi dan tekanan darah naik, mulut kering, gelisah, konstipasi. Sedangkan respon kognitif yaitu lahan persepsi menyempit, rangsangan luar tidak mampu diterima, berfokus pada apa yang menjadi perhatiaannya.

3. Kecemasan Berat

Kecemasan berat sangat mempengaruhi persepsi individu, individu cenderung untuk memusatkan pada sesuatu yang terinci dan spesifik, serta tidak dapat berfikir tentang hal lain. Semua perilaku ditujukan untuk mengurangi ketegangan. Tanda dan gejala dari kecemasan berat yaitu : persepsinya sangat kurang, berfokus pada hal yang detail, rentang perhatian sangat terbatas, tidak dapat berkonsentrasi atau menyelesaikan masalah, serta tidak dapat belajar secara efektif. Pada tingkatan ini individu mengalami sakit kepala, pusing, mual, gemetar, insomnia, palpitasi, takikardi, hiperventilasi, sering buang air kecil maupun besar, dan diare. Secara emosi individu mengalami ketakutan serta seluruh perhatian terfokus pada dirinya.

4. Panik

Pada tingkat panik dari kecemasan berhubungan dengan terperangah, ketakutan, dan teror. Karena mengalami kehilangan kendali, individu yang mengalami panik tidak dapat melakukan sesuatu walaupun dengan pengarahan. Panik menyebabkan peningkatan aktivitas motorik, menurunnya kemampuan berhubungan dengan orang lain, persepsi yang menyimpang, kehilangan pemikiran yang rasional. Kecemasan ini tidak sejalan dengan kehidupan, dan jika berlangsung lama dapat terjadi kelelahan yang sangat bahkan kematian. Tanda dan gejala dari tingkat panik yaitu tidak dapat fokus pada suatu kejadian. 


\subsubsection{Rentang respon}

Menurut Stuart (2006) "menjelaskan rentang respon individu terhadap cemas berfluktuasi antara respon adaptif dan maladaptif. Rentang respon yang paling adaptif adalah antisipasi dimana individu siap siaga untuk beradaptasi dengan cemas yang mungkin muncul. Sedangkan rentang yang paling maladaptif adalah panik dimana individu sudah tidak mampu lagi berespon terhadap cemas yang dihadapi sehingga mengalami ganguan fisik, perilaku maupun kognitif. Seseorang berespon adaptif terhadap kecemasannya maka tingkat kecemasan yang dialaminya ringan, semakin maladaptif respon seseorang terhadap kecemasan maka semakin berat pula tingkat kecemasan yang dialaminya.

\subsubsection{Ciri-ciri Kecemasan}

Menurut Anggraini \& Oliver (2019) kecemasan mempunyai ciri-ciri tersendiri, diantaranya :

1. Ciri fisik dari kecemasan meliputi kegelisahan, kegugupan, tangan atau anggota tubuh lain yang bergetar atau gemetar, sensasi dari pita ketat yang mengikat disekitar dahi, banyak berkeringat, pening atau pingsan, sulit berbicara, sulit bernapas, jari-jari atau anggota tubuh lain jadi dingin, panas dingin, dll

2. Ciri behavioral dari kecemasan meliputi perilaku menghindar, perilaku melekat dan dependen dan perilaku terguncang.

3. Ciri kognitif dari kecemasan meliputi khawatir tentang sesuatu, perasaan terganggu akan ketakutan atau apprehensi terhadap sesuatu yang terjadi di masa depan, keyakinan bahwa sesuatu yang mengerikan akan terjadi tanpa ada penjelasan yang jelas, merasa terancam oleh orang ayau peristiwa yang normalnya haya sedikit atau tidak mendapat perhatian, ketakutan akan ketidakmampuan untuk mengatasi masalah. 


\subsubsection{Tanda dan Gejala Kecemasan}

Menurut Ii (2021) adapun tanda dan gejala pada kecemasan, yaitu :

1. Tanda-Tanda Fisik Kecemasan,

Tanda fisik kecemasan diantaranya yaitu : kegelisahan, kegugupan,, tangan atau anggota tubuh yang bergetar atau gemetar, sensasi dari pita ketat yang mengikat di sekitar dahi, kekencangan pada pori-pori kulit perut atau dada, banyak berkeringat, telapak tangan yang berkeringat, pening atau pingsan, mulut atau kerongkongan terasa kering, sulit berbicara, sulit bernafas, bernafas pendek, jantung yang berdebar keras atau berdetak kencang, suara yang bergetar, jari-jari atau anggota tubuh yang menjadi dingin, pusing, merasa lemas atau mati rasa, sulit menelan, kerongkongan merasa tersekat, leher atau punggung terasa kaku, sensasi seperti tercekik atau tertahan, tangan yang dingin dan lembab, terdapat gangguan sakit perut atau mual, panas dingin, sering buang air kecil, wajah terasa memerah, diare, dan merasa sensitif atau "mudah marah".

2. Tanda-Tanda Behavioral Kecemasan

Tanda-tanda behavorial kecemasan diantaranya yaitu : perilaku menghindar, perilaku melekat dan dependen, dan perilaku terguncang.

3. Tanda-Tanda Kognitif Kecemasan

Tanda-tanda kognitif kecemasan diantaranya : khawatir tentang sesuatu, perasaan terganggu akan ketakutan atau aprehensi terhadap sesuatu yang terjadi di masa depan, keyakinan bahwa sesuatu yang mengerikan akan segera terjadi (tanpa ada penjelasan yang jelas), terpaku pada sensasi ketubuhan, sangat waspada terhadap sensasi ketubuhan, merasa terancam oleh orang atau peristiwa yang normalnya hanya sedikit atau tidak mendapat perhatian, ketakutan akan kehilangan kontrol, ketakutan akan ketidakmampuan untuk mengatasi masalah, berpikir bahwa dunia mengalami keruntuhan, berpikir bahwa 
semuanya tidak lagi bisa dikendalikan, berpikir bahwa semuanya terasa sangat membingungkan tanpa bisa diatasi, khawatir terhadap hal-hal yang sepele, berpikir tentang hal mengganggu yang sama secara berulang-ulang, berpikir bahwa harus bisa kabur dari keramaian (kalau tidak pasti akan pingsan), pikiran terasa bercampur aduk atau kebingungan, tidak mampu menghilangkan pikiran-pikiran terganggu, berpikir akan segera mati (meskipun dokter tidak menemukan sesuatu yang salah secara medis), khawatir akan ditinggal sendirian, dan sulit berkonsentrasi atau memfokuskan pikiran.

\subsection{Konsep Asuhan Keperawatan}

\subsubsection{Pengkajian}

1. Faktor Predisposisi

Berbagai teori telah dikembangkan untuk menjelaskan asal ansietas (Waryuningsih, 2021) :

a. Teori Psiko analitik

Ansietas adalah konflik emosional yang terjadi antara dua elemen kepribadian, ID dan superego. ID mewakili dorongan insting dan impuls primitif seseorang, sedangkan superego mencerminkan hati nurani seseorang dan dikendalikan oleh norma-norma budaya seseorang. Ego atau Aku, berfungsi menengahi hambatan dari dua elemen yang bertentangan dan fungsi ansietas adalah mengingatkan ego bahwa ada bahaya.

b. Teori Interpersonal

Ansietas timbul dari perasaan takut terhadap tidak adanya penerimaan dari hubungan interpersonal. Ansietas juga berhubungan dengan perkembangan, trauma seperti perpisahan dan kehilangan sehingga menimbulkan kelemahan spesifik.Orang dengan harga diri rendah mudah mengalami perkembangan ansietas yang berat. 
c. Teori Perilaku

Ansietas merupakan produk frustasi yaitu segala sesuatu yang mengganggu kemampuan seseorang untuk mencapai tujuan yang diinginkan.Daftar tentang pembelajaran meyakini bahwa individu yang terbiasa dalam kehidupan dininya dihadapkan pada ketakutan yng berlebihan lebih sering menunjukkan ansietas pada kehidupan selanjutnya.

d. Kajian Keluarga

Menunjukkan bahwa gangguan ansietas merupakan hal yang biasa ditemui dalam suatu keluarga. Ada tumpang tindih dalam gangguan ansietas dan antara gangguan ansietas dengan depresi.

e. Kajian Biologis

Menunjukkan bahwa otak mengandung reseptor khusus benzodiazepine. Reseptor ini mungkin membantu mengatur ansietas penghambat dalam aminobutirik. Gamma neuroregulator (GABA) juga mungkin memainkan peran utama dalam mekanisme biologis berhubungan dengan ansietas sebagaimana halnya endorfin. Selain itu telah dibuktikan kesehatan umum seseorang mempunyai akibat nyata sebagai predisposisi terhadap ansietas. Ansietas mungkin disertai dengan gangguan fisik dan selanjutnya menurunkan kapasitas seseorang untuk mengatasi stressor.

\section{Faktor Presipitasi}

Stressor pencetus mungkin berasal dari sumber internal atau eksternal. Stressor pencetus dapat dikelompokkan menjadi 2 kategori (Pratiwi, Widianti \& Solehati, 2017) :

a. Ancaman terhadap integritas seseorang meliputi ketidak mampuan fisiologis yang akan datang atau menurunnya kapasitas untuk melakukan aktifitas hidup sehari-hari. 
b. Ancaman terhadap sistem diri seseorang dapat membahayakan identitas, harga diri dan fungsi sosial yang terintegrasi seseorang.

3. Perilaku

Kecemasan dapat diekspresikan secara langsung melalui perubahan fisiologi dan perilaku dan secara tidak langsung melalui timbulnya gejala atau mekanisme koping dalam upaya melawan kecemasan. Intensitas perilaku akan meningkat sejalan dengan peningkatan tingkat kecemasan.

a. Respon Fisiologis Terhadap Ansietas

\begin{tabular}{|c|c|}
\hline Sistem Tubuh & Respons \\
\hline Kardiovaskuler & $\begin{array}{l}\text { 1. Palpitasi. } \\
\text { 2. Jantungberdebar. } \\
\text { 3. Tekanan darah meningkat dan } \\
\text { denyut nadi menurun. } \\
\text { 4. Rasa mau pingsan dan pada akhirnya } \\
\text { pingsan. }\end{array}$ \\
\hline Pernafasan & $\begin{array}{l}\text { 1. Napas cepat. } \\
\text { 2. Pernapasan dangkal. } \\
\text { 3. Rasa tertekan pada dada. } \\
\text { 4. Pembengkakan pada tenggorokan. } \\
\text { 5. Rasa tercekik. } \\
\text { 6. Terengah-engah. }\end{array}$ \\
\hline Neuromuskular & $\begin{array}{l}\text { 1. Peningkatan reflek. } \\
\text { 2. Reaksi kejutan. } \\
\text { 3. Insomnia. } \\
\text { 4. Ketakutan. } \\
\text { 5. Gelisah. } \\
\text { 6. Wajah tegang. } \\
\text { 7. Kelemahan secara umum. } \\
\text { 8. Gerakanlambat. } \\
\text { 9. Gerakan yang janggal. }\end{array}$ \\
\hline Gastrointestinal & $\begin{array}{l}\text { 1. Kehilangan nafsu makan. } \\
\text { 2. Menolak makan. } \\
\text { 3. Perasaan dangkal. } \\
\text { 4. Rasa tidak nyaman pada abdominal. } \\
\text { 5. Rasa terbakar pada jantung. } \\
\text { 6. Nausea. } \\
\text { 7. Diare. }\end{array}$ \\
\hline Perkemihan & $\begin{array}{l}\text { 1. Tidak dapat menahan kencing. } \\
\text { 2. Sering kencing. }\end{array}$ \\
\hline
\end{tabular}




\begin{tabular}{|l|l|}
\hline Kulit & $\begin{array}{l}\text { 1. Rasa terbakar pada mukosa. } \\
\text { 2. Berkeringat banyak pada telapak } \\
\text { tangan. }\end{array}$ \\
3. Gatal-gatal. \\
4. Perasaan panas atau dingin pada \\
$\begin{array}{l}\text { kulit. } \\
\text { 5. Muka pucat dan bekeringat diseluruh } \\
\text { tubuh. }\end{array}$ \\
\hline
\end{tabular}

b. Respon Perilaku Kognitif

\begin{tabular}{|c|c|}
\hline Sistem & Respons \\
\hline Perilaku & $\begin{array}{ll}\text { 1. } & \text { Gelisah. } \\
\text { 2. } & \text { Ketegangan fisik. } \\
\text { 3. } & \text { Tremor. } \\
\text { 4. } & \text { Gugup. } \\
\text { 5. } & \text { Bicaracepat. } \\
\text { 6. } & \text { Tidak ada koordinasi. } \\
\text { 7. } & \text { Kecenderungan untuk celaka. } \\
\text { 8. } & \text { Menarik diri. } \\
\text { 9. } & \text { Menghindar. } \\
\text { 10. } & \text { Terhambat melakukan aktifitas. }\end{array}$ \\
\hline Kognitif & $\begin{array}{l}\text { 1. Gangguan perhatian. } \\
\text { 2. Konsentrasi hilang. } \\
\text { 3. Pelupa. } \\
\text { 4. Salah tafsir. } \\
\text { 5. Adanya bloking pada pikiran. } \\
\text { 6. Menurunnya lahanpersepsi. } \\
\text { 7. Kreatif dan produktif menurun. } \\
\text { 8. Bingung. } \\
\text { 9. Khawatir yang berlebihan. } \\
\text { 10. Hilang menilai objektifitas. } \\
\text { 11. Takut akan kehilangan kendali. } \\
\text { 12. Takut yang berlebihan. }\end{array}$ \\
\hline Afektif & $\begin{array}{l}\text { 1. Mudah terganggu. } \\
\text { 2. Tidak sabar. } \\
\text { 3. Gelisah. } \\
\text { 4. Tegang. } \\
\text { 5. Nerveus. } \\
\text { 6. Ketakutan. } \\
\text { 7. Alarm. } \\
\text { 8. Tremor. } \\
\text { 9. Gugup. } \\
\text { 10. Gelisah. }\end{array}$ \\
\hline
\end{tabular}


4. Sumber Koping

Individu dapat mengalami stress dan ansietas dengan menggerakkan sumber koping tersebut di lingkungan. Sumber koping tersebut sebagai modal ekonomok, kemampuan penyelesaian masalah, dukungan sosial dan keyakinan budaya dapat membantu seseorang mengintegrasikan pengalaman yang menimbulkan stress dan mengadopsi strategi koping yang berhasil.

5. Mekanisme Koping

Ketika mengalami ansietas individu menggunakan berbagai mekanisme koping untuk mencoba mengatasinya dan ketidakmampuan mengatasi ansietas secara konstruktif merupakan penyebab utama terjadinya perilaku patologis. Ansietas tingkat ringan sering ditanggulangi tanpa yang serius. Tingkat ansietas sedang dan berat menimbulkan 2 jenis mekanisme koping :

a. Reaksi yang berorientasi pada tugas, yaitu upaya yang disadari dan berorientasi pada tindakan untuk memenuhi secara realitis tuntutan situasi stress.

b. Mekanisme pertahanan ego, membantu mengatasi ansietas ringan dan sedang, tetapi jika berlangsung pada tingkat sadar dan melibatkan penipuan diri dan distorsi realitas, maka mekanisme ini dapat merupakan respon maladaptif terhadap stress.

\subsubsection{Diagnosa Keperawatan}

Adapun diagnosa yang biasanya muncul adalah :

1. Koping Individu Tidak Efektif

2. Kecemasan

3. Ketidakberdayaan

4. Isolasi Sosial

5. Perubahan Proses Berfikir 


\subsubsection{Intervensi Keperawatan Kecemasan}

Tujuan :

1. Klien mampu mengenal pengertian penyebab tanda gejala dan akibat

2. Klien mampu mengetahui cara mengatasi ansietas

3. Klien mampu mengatasi ansietas dengan melakukan latihan relaksasi tarik nafas dalam

4. Klien mampu mengatasi ansietas dengan melakukan latihan distraksi

5. Klien mampu mengatasi ansietas dengan melakukan hipnotis lima jari

6. Klien mampu merasakan manfaat dari latihan yang dilakukan

7. Klien mampu membedakan perasaan sebelum dan sesudah latihan

Tindakan :

1. Kaji tanda dan gejala ansietas dan kemampuan klien mengurangi kecemasan

2. Jelaskan tanda dan gejala, penyebab dan akibat darikecemasan

3. Latihan cara mengatasi kecemasan :

a. Teknik relaksasi napas dalam

b. Distraksi : bercakap-cakap hal positif

c. Hipnotis 5 jari fokus padahal-hal yang positif

4. Bantu klien melakukan latihan sesuai dengan jadwal kegiatan 
BAB 3

TINJAUAN KASUS

\subsection{Pengkajian Keperawatan}

\begin{tabular}{|ll|l|}
\hline Nama & : Tn.A & Kondisi saat MRS:- \\
Usia & $: 46$ Tahun & Kondisi saat ini : \\
No. Reg & $:-$ & Tn. A mengeluh badannya terasa lemas, kehilangan selera makan, tekanan \\
Ruangan & $:-$ & darah tinggi sehingga Tn.A tidak mampu melakukan aktivitas seperti \\
Tanggal Masuk RS & $:-$ & biasanya, hingga membuat Tn.A merasa takut, gelisah dan tidak dapat \\
Tanggal Pengkajian & $:$ 06 Oktober 2021 & melakukan aktifitas seperti biasa. \\
Alamat & $\begin{array}{l}\text { Sesa Penggalangan Tebing } \\
\text { Syandar }\end{array}$ & \\
\hline
\end{tabular}

1. Faktor Predisposisi Dan Faktor Presipitasi

\begin{tabular}{|c|c|c|c|c|}
\hline \multirow[b]{2}{*}{ Faktor predisposisi } & \multicolumn{3}{|c|}{ Faktor presipitasi } & \multirow[b]{2}{*}{ STRESSOR } \\
\hline & Nature & Origin & $\begin{array}{c}\text { Number \& } \\
\text { Timing }\end{array}$ & \\
\hline $\begin{array}{l}\text { Biologis: } \\
\text { 1. Hipertensi } \\
\text { 2. Tn.A menderita gagal ginjal kronis } 2 \text { tahun yang } \\
\text { lalu } \\
\text { 3. Tn.A sering mengkonsumsi makanan tinggi } \\
\text { garam } \\
\text { 4. Tn. A tidak rutin check up kepelayanankesehatan }\end{array}$ & $\begin{array}{l}\text { - Badannya terasa } \\
\text { lemas, kehilangan } \\
\text { selera makan, } \\
\text { tekanan darah tinggi }\end{array}$ & Internal & $\begin{array}{l}\text { Sejak } 2 \\
\text { minggu } \\
\text { yang lalu }\end{array}$ & - Hipertensi \\
\hline
\end{tabular}




\begin{tabular}{|c|c|c|c|c|}
\hline $\begin{array}{l}\text { Psikologis : } \\
\text { 1. Tn. A memiliki kepribadian yang terbuka setiap } \\
\text { ada masalah akan dibicarakan denganistrinya } \\
\text { 2. Tn. A merasa gemetaran, mudah lelah, dan } \\
\text { jantung berdebarkencang }\end{array}$ & $\begin{array}{l}\text { Merasa takut, } \\
\text { gelisah dan tidak } \\
\text { dapat melakukan } \\
\text { aktifitas seperti } \\
\text { biasa. }\end{array}$ & Internal & $\begin{array}{l}\text { Sejak } 2 \\
\text { minggu yang } \\
\text { lalu }\end{array}$ & $\begin{array}{l}\text { - Cemas, takut, } \\
\text { lemas. }\end{array}$ \\
\hline $\begin{array}{l}\text { Sosiocultural : } \\
\text { 1. Tn. A seorang laki-laki umur 46tahun } \\
\text { 2. Tn. A menikah dan memiliki } 2 \text { oranganak } \\
\text { 3. Tn. A merupakan kepala rumahtangga } \\
\text { 4. Sebelumnya Tn. S aktif terlibat dalam kegiatan } \\
\text { dilingkungan tempat tinggal seperti kebaktian } \\
\text { (PA) dalam kegiatangereja } \\
\text { 5. Tn. A beragama kristen protestan dan taat } \\
\text { menjalankanibadah } \\
\text { 6. Tn. A jarang check up tentangpenyakitnya }\end{array}$ & & & & \\
\hline Genogram : & $\begin{array}{l}\text { Tn. A memiliki seo } \\
\text { anak. }\end{array}$ & istri dan & setelah menik & hemiliki 2 orang \\
\hline
\end{tabular}




\begin{tabular}{|c|c|c|c|c|c|c|}
\hline STRESSOR & KOGNITIF & AFEKTIF & FISIOLOGIS & PERILAKU & SOSIAL & $\begin{array}{r}\text { DIAGNOSA } \\
\text { KEPERAWAT } \\
\text { AN }\end{array}$ \\
\hline $\begin{array}{l}\text { BIOLOGIS } \\
\text { - Hipertensi }\end{array}$ & $\begin{array}{l}\text { - } \text { Menurut Tn.A } \\
\text { penyakit Hipertensi } \\
\text { diakibatkan karena } \\
\text { pengkonsumsi } \\
\text { makanan tinggi } \\
\text { garam } \\
\text { - Tidak tahu apa } \\
\text { yang harus } \\
\text { dilakukan untuk } \\
\text { penyakitnya } \\
\text { - Menganggap } \\
\text { penyakit yang } \\
\text { dideritaserius }\end{array}$ & $\begin{array}{l}\text { - Tn. A merasa } \\
\text { sedih dan } \\
\text { juga bingung } \\
\text { dengan } \\
\text { kondisi } \\
\text { penyakitnya } \\
\text { saatini }\end{array}$ & $\begin{array}{l}\text { - } \text { Cemas } \\
\text { - Sulit tidur } \\
\text { - Tidak } \\
\text { nafsu makan } \\
\text { - Tn.A tampak } \\
\text { lemas } \\
\text { - Pemeriksaan } \\
\text { TTV } \\
\text { TD: } 140 / 90 \\
\text { mmHg } \\
\mathrm{N}: 86 \quad \mathrm{x} \\
\text { /menit P : 20 } \\
\mathrm{x} / \mathrm{menit} \mathrm{S}: \\
37{ }^{0} \mathrm{C}\end{array}$ & $\begin{array}{l}\text { - Tn. A jarang } \\
\text { kontrol ke } \\
\text { rumahsakit } \\
\text { - Ekspresi } \\
\text { mukalesu } \\
\text { - Tn.A tampak } \\
\text { lemas dan } \\
\text { gemetaran }\end{array}$ & $\begin{array}{l}\text { - Pasien } \\
\text { mendatangi } \\
\text { dan } \\
\text { menggunakan } \\
\text { fasilitas } \\
\text { kesehatan } \\
\text { yang ada } \\
\text { untuk mencari } \\
\text { kesembuhan } \\
\text { terhadap } \\
\text { masalah yang } \\
\text { dihadapi saatini }\end{array}$ & - Ansietas \\
\hline
\end{tabular}




\begin{tabular}{|c|c|c|c|c|c|c|}
\hline $\begin{array}{l}\text { PSIKOLOGIS } \\
\text { - Sedih, cemas, } \\
\text { lemas dan } \\
\text { Kehilangan selera } \\
\text { makan dengan } \\
\text { kondisi penyakit } \\
\text { dan pengobatan } \\
\text { serta } \\
\text { Perawatannya }\end{array}$ & $\begin{array}{l}\text { - Tn. S tahu bahwa } \\
\text { badannya terasa } \\
\text { lemas, kehilangan } \\
\text { selera makan, } \\
\text { tekanan darah } \\
\text { tinggi sehingga Tn.A } \\
\text { tidak mampu } \\
\text { melakukan aktivitas } \\
\text { seperti biasanya, } \\
\text { hingga membuat Tn. } \\
\text { A merasa takut, } \\
\text { gelisah dan tidak } \\
\text { dapat melakukan }\end{array}$ & $\begin{array}{l}\text { - Merasa kesal } \\
\text { dengan } \\
\text { penyakitnya } \\
\text { yang tidak } \\
\text { sembuh- } \\
\text { sembuh }\end{array}$ & $\begin{array}{l}\text { - Sakit kepala } \\
\text { - Sulit tidur dan } \\
\text { sering } \\
\text { terbangun } \\
\text { apabilatidur } \\
\text { - Tidak nafsu } \\
\text { makan } \\
\text { - Tn. A tampak } \\
\text { lemas } \\
\text { - Wajah Tn.A } \\
\text { tampaklemas } \\
\text { - Pemeriksaan } \\
\text { TTV } \\
\text { TD: } 140 / 90 \\
\text { mmhg } \\
\mathrm{N}: 86 \mathrm{x} / \mathrm{menit} \\
\mathrm{P}: 20 \mathrm{x} / \text { menit } \\
\mathrm{S}: 370 \mathrm{C}\end{array}$ & $\begin{array}{l}\text { - Tampak } \\
\text { cemas } \\
\text { dan tidak } \\
\text { tenang } \\
\text { - Kadang Tn. A } \\
\text { tampak } \\
\text { murung } \\
\text { - Tn. A } \\
\text { tampak } \\
\text { gelisah } \\
\text { - Tn. A } \\
\text { tampak pasif } \\
\text { dalam } \\
\text { menerima } \\
\text { perawatan } \\
\text { - Tn. A } \\
\text { Menunduk } \\
\text { saat bercerita }\end{array}$ & 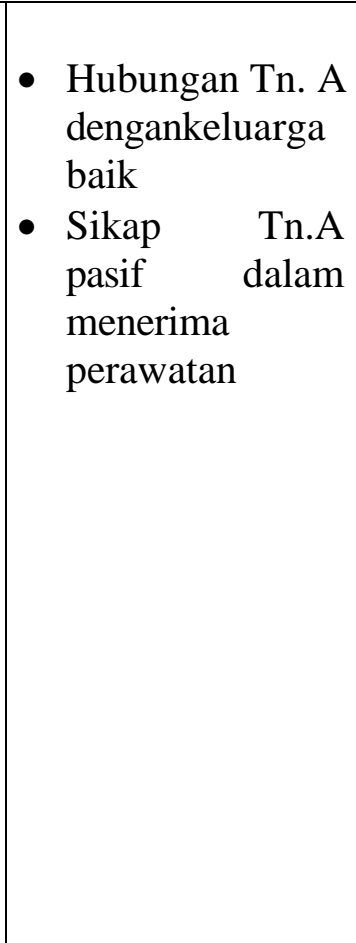 & $\begin{array}{ll}\text { - } & \text { Ansietas } \\
\text { - } & \text { Ketidakber } \\
& \text { dayaan }\end{array}$ \\
\hline
\end{tabular}




\begin{tabular}{|c|c|c|c|c|c|c|}
\hline $\begin{array}{l}\text { SOSIAL BUDAYA } \\
\text { • Tn. S merasa } \\
\text { memikirkan } \\
\text { keluarga yang } \\
\text { masih yang } \\
\text { harus menjaga } \\
\text { dan } \\
\text { merawatnya } \\
\text { setiaphari. }\end{array}$ & $\begin{array}{l}\text { - Tn. A merasa harga } \\
\text { dirinya rendah } \\
\text { keadaannya dengan } \\
\text { keadaan yang tidak } \\
\text { bisa bekerja } \\
\text { bingung memikirkan } \\
\text { anak- anak, menurut } \\
\text { pasien, dukungan } \\
\text { keluarga nomor satu } \\
\text { - Tn. A berfikir ia } \\
\text { selalu } \\
\text { merepotkan } \\
\text { keluarga bila } \\
\text { terlalu lama } \\
\text { dalam keadaan } \\
\text { sepertiini } \\
\text { - Merasakasihan } \\
\text { kepada keluarga yang } \\
\text { harus menjaga dan } \\
\text { merawat klien }\end{array}$ & $\begin{array}{l}\text { - Merasa } \\
\text { khawatir dan } \\
\text { sedih kepada } \\
\text { istri yang } \\
\text { merawatnya } \\
\text { setiaphari } \\
\text { - Merasa } \\
\text { bersalah karena } \\
\text { merasa } \\
\text { merepotkan } \\
\text { suami } \\
\text { - Merasa bosan } \\
\text { dengan keadaan } \\
\text { sekarang }\end{array}$ & $\begin{array}{l}\text { - } \text { Pusing } \\
\text { - Mual } \\
\text { - Mulut tampak } \\
\text { kering } \\
\text { - Sulit tidur } \\
\text { - Tidak nafsu } \\
\text { makan } \\
\text { - Tn. A tampak } \\
\text { lemas } \\
\text { - Wajah Tn. A } \\
\text { tampak pucat } \\
\text { Pemeriksaan }\end{array}$ & $\begin{array}{l}\text { - Tn. A } \\
\text { tampak } \\
\text { gelisah }\end{array}$ & $\begin{array}{l}\text { - Hubungan } \\
\text { Tn.A dengan } \\
\text { keluarga baik } \\
\text { - Hubungan } \\
\text { Tn.A dengan } \\
\text { petugas } \\
\text { kesehatanbaik } \\
\text { - Tn.A tetap } \\
\text { mengikuti } \\
\text { program } \\
\text { pengobatan }\end{array}$ & $\begin{array}{l}\text { - Harga } \\
\text { Diri Rendah }\end{array}$ \\
\hline
\end{tabular}


Pohon Diagnosis

\section{KETIDAKBERDAYAAN}

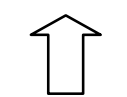

\section{KECEMASAN}

PENYAKIT HIPERTENSI

\section{SUMBER KOPING}

\begin{tabular}{|c|c|c|c|c|c|}
\hline $\begin{array}{c}\text { DIAGNOSA } \\
\text { KEPERAWATAN }\end{array}$ & PERSONAL ABILITY & $\begin{array}{c}\text { SOSIAL } \\
\text { SUPPORT }\end{array}$ & $\begin{array}{c}\text { MATERIAL } \\
\text { ASSETS }\end{array}$ & $\begin{array}{l}\text { POSITIE } \\
\text { BELIEFS }\end{array}$ & TERAPI \\
\hline Ansietas & $\begin{array}{l}\text { - Tn.A mampu } \\
\text { mengungkapkan } \\
\text { perasaancemas } \\
\text { - Tn.A mengatakan bila } \\
\text { cemasnya memuncak } \\
\text { maka ia akanberdoa }\end{array}$ & $\begin{array}{l}\text { Tn. A mendapat } \\
\text { dukungan dari } \\
\text { keluarga untuk } \\
\text { kesembuhannya } \\
\text { dan keluarga } \\
\text { Tn.A bergantian } \\
\text { merawatpasien }\end{array}$ & $\begin{array}{l}\text { - Sosial ekonomi } \\
\text { Tn.A menengah } \\
\text { dan pengobatan } \\
\text { ditanggung biaya } \\
\text { pribadi } \\
\text { - Jarak rumah } \\
\text { Tn.A dengan } \\
\text { tempat pelayanan } \\
\text { kesehatan lebih } \\
\text { kurang } 1 \mathrm{~km}\end{array}$ & $\begin{array}{l}\text { - Tn. A percaya bahwa } \\
\text { petugas kesehatan } \\
\text { akanmembantunya } \\
\text { - Tn. A berharap cepat } \\
\text { sembuh agar tidak } \\
\text { merepotkan } \\
\text { keluarga }\end{array}$ & $\begin{array}{ll}\text { Terapi spesialis: } \\
\text { - } & \text { Relaksasi } \\
& \text { progresif } \\
\text { - } & \text { Psikoedukasi } \\
& \text { keluarga } \\
\text { - } & \text { Behavior } \\
& \text { therapy } \\
\text { - } & \text { Psikoedukasi } \\
& \text { keluarga }\end{array}$ \\
\hline
\end{tabular}




\begin{tabular}{|c|c|c|c|c|c|}
\hline Kurang pengetahuan & $\begin{array}{l}\text { - Tn. A mampu } \\
\text { mengenal dan menilai } \\
\text { penyakitnya } \\
\text { - Tn. A mampu melatih } \\
\text { cara hidupsehat }\end{array}$ & $\begin{array}{l}\text { Tn. A mendapat } \\
\text { dukungan dari } \\
\text { keluarga untuk } \\
\text { kesembuhannya } \\
\text { terutama dari } \\
\text { keluarganya } \\
\text { - Keluarga Tn. A } \\
\text { bergantian } \\
\text { menjaga dan } \\
\text { mengunjungi } \\
\text { pasien }\end{array}$ & $\begin{array}{l}\text { - Sosial ekonomi } \\
\text { Tn. A menengah } \\
\text { - Tn. A tinggal di } \\
\text { rumahsendiri } \\
\text { - Sarana dan } \\
\text { prasarana } \\
\text { tersedia } \\
\text { - Biaya } \\
\text { pengobatan } \\
\text { ditanggung } \\
\text { keluarga Tn.A } \\
\text { sendiri } \\
\text { - Jarak rumah } \\
\text { Tn.A dengan } \\
\text { tempat pelayanan } \\
\text { kesehatan sekitar } \\
1 \text { km }\end{array}$ & $\begin{array}{l}\text { - Tn. A percaya bahwa } \\
\text { petugas kesehatan } \\
\text { akanmembantunya } \\
\text { - Tn.A berharap } \\
\text { cepat sembuh agar } \\
\text { tidak merepotkan } \\
\text { keluarganya } \\
\text { - Tn.A selalu } \\
\text { berdoa untuk } \\
\text { kesembuhan } \\
\text { penyakitnya } \\
\text { Tn. A yakin, bila ia } \\
\text { mengikuti } \\
\text { petunjuk dan saran } \\
\text { dari petugas } \\
\text { kesehatan maka ia } \\
\text { akan cepatsembuh } \\
\text { Tn. A yakin keluarga } \\
\text { mendukung supaya } \\
\text { lekassembuh }\end{array}$ & $\begin{array}{l}\text { Terapi generalis: } \\
\text { - } \quad \text { SP 1-2 kurang } \\
\text { pengetahuan } \\
\text { - } \text { Terapi } \\
\text { spesialis } \\
\text { - Terapi } \\
\text { suportif }\end{array}$ \\
\hline
\end{tabular}




\section{MEKANISME KOPING}

\begin{tabular}{|c|c|}
\hline HAL YANG DILAKUKAN & ANALISA \\
\hline $\begin{array}{l}\text { - Tn. A mengatakan bila ada masalah, maka ia akan membicarakan } \\
\text { dengan istri dan keluarga untuk mencari jalankeluarnya } \\
\text { - Bila sakit Tn. A berobat ke pelayanankesehatan } \\
\text { - Tn. A taat menjalankan ibadah sesuai dengan keyakinan yang ia } \\
\text { miliki } \\
\text { - Tn. A selalu berdoa kepada Tuhan untukkesembuhannya }\end{array}$ & $\begin{array}{l}\text { - Konstruktif: } \\
\text { * Tn.A mengatakan bila ada masalah, maka ia akan } \\
\text { membicarakan dengan keluarga untuk mencari jalan } \\
\text { keluarnya } \\
\text { * Bila sakit Tn. A berobat ke pelayanankesehatan } \\
\text { * Tn.A taat menjalankan ibadah sesuai dengan } \\
\text { keyakinannya } \\
\text { * Tn. A selalu berdoa kepada Tuhanuntuk } \\
\text { kesembuhannya. } \\
\text { - Destruktif : - }\end{array}$ \\
\hline
\end{tabular}




\section{STATUS MENTAL}

\begin{tabular}{|l|l|}
\hline 1. Penampilan & Bersih, dan rapi \\
\hline 2. Pembicaraan & Ramah dan mau menceritakan semua hal yang dialami saat ini \\
\hline 3. Aktivitas motoric & Mampu berinteraksi \\
\hline $\begin{array}{l}\text { 4. Interaksi selama } \\
\text { wawancara }\end{array}$ & Ada kontak mata saat wawancara namun tidak tetap \\
\hline 5. Alam perasaan & Sedih, merasa cemas ,takut dan bingung mengenai penyakit yang dialami \\
\hline 6. Afek & Datar \\
\hline 7. Persepsi & Tidak ada gangguan persepsi dan sensori \\
\hline 8. Isi piker & Tidak ada gangguan isi pikir \\
\hline 9. Proses piker & Tidak ada ganggu proses pikir \\
\hline 10. Tingkat kesadaran & Normal \\
\hline 11. Daya ingat & Normal \\
\hline 12. Kemampuan berhitung & Tidak ada gangguan dalam berhitung \\
\hline 13. Penilaian & Tn. A mengambil keputusan saat merasa sakit dengan beribadah dan berdoa \\
\hline 14. Daya tilik diri & Tn. A menyadari memang merasa cemas \\
\hline
\end{tabular}




\subsection{DIAGNOSA DAN TERAPI}

\begin{tabular}{|l|c|}
\hline \multicolumn{1}{|c|}{ DIAGNOSA KEPERAWATAN DAN TERAPI } & KEPERAWATAN \\
& DIAGNOSA MEDIS DAN TERAPI MEDIS \\
\hline 1. Ansietas & Hipens \\
- Sp1 : & Mendiskusikan penyebab, terjadinya proses terjadi, tanda \\
dan gejala danakibat & \\
- Sp2: & Melatih teknik releksasifisik \\
- Sp3 : & \\
Melatih mengatasi ansietas dengan distraksi dan hipnotis & \\
limajari & \\
Sp4: & \\
Melatih mengatasi ansietas melalui kegiatanspiritual & \\
2. Ketidakberdayaan & \\
Sp1. & \\
Assement ketidakerdayaan dan latihan berpikirpositif & \\
Sp2. & \\
Manfaat mengembangkan harapan positif dan latihan & \\
mengontrolperasaan & \\
3. Koping inefektif &
\end{tabular}




\subsection{IMPLEMENTASI TINDAKAN KPERAWATAN DAN EVALUASI}

\begin{tabular}{|c|c|}
\hline IMPLEMENTASI TINDAKAN KEPERAWATAN & EVALUASI \\
\hline $\begin{array}{l}\text { 1. Melakukan salamteraupetik } \\
\text { 2. Kaji tanda dan gejala ansietas dan kemampuan klienmengurangi } \\
\text { kecemasan } \\
\text { 3. Jelaskan tanda dan gejala, penyebab dan akibat darikecemasan } \\
\text { 4. Latihan cara mengatasi kecemasan: } \\
\text { - Teknik relaksasi napasdalam } \\
\text { - Distraksi : bercakap-cakap halpositif } \\
\text { - Hipnotis } 5 \text { jari fokus pada hal-hal yangpositif }\end{array}$ & $\begin{array}{l}\text { S: Pasien senang } \\
\text { O : Pasien mampu melakukan nafas dalam dengan } \\
\quad \text { motivasi Pasien mampu latihan distraksi dengan } \\
\quad \text { mandiri Pasien mampu melakukan hipnotis } 5 \text { jari } \\
\quad \text { dengan bantuan } \\
\text { A: Ansietas (+) } \\
\text { P : } \\
\quad \text { Latihan cara mengatasikecemasan: } \\
\checkmark \text { Teknik relaksasi napas dalam 3xsehari } \\
\checkmark \text { Distraksi : bercakap-cakap hal positif 3x sehari } \\
\checkmark \text { Hipnotis } 5 \text { jari fokus } 3 x \text { sehari }\end{array}$ \\
\hline
\end{tabular}




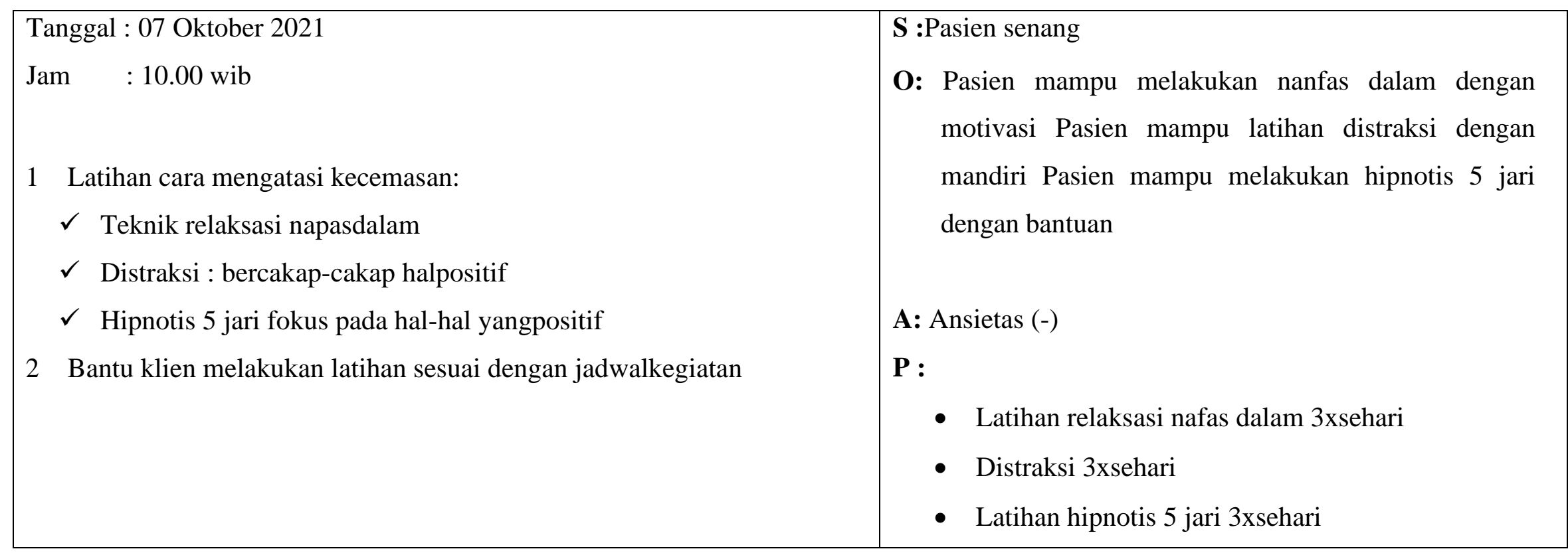




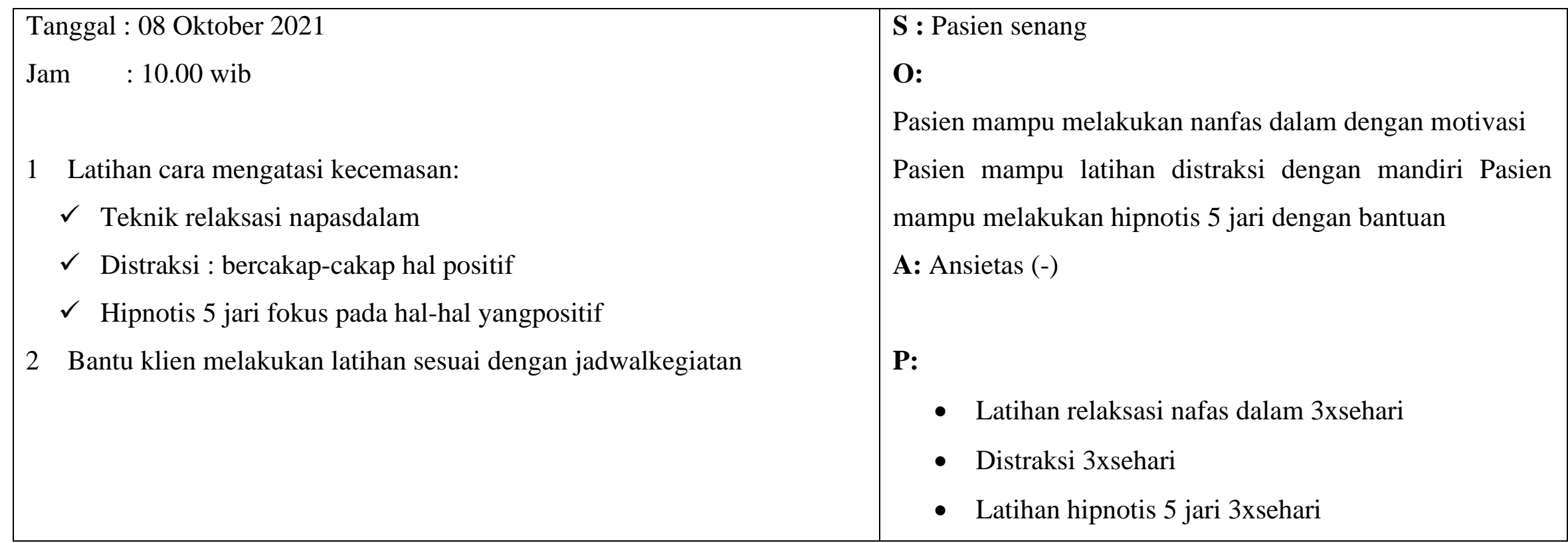




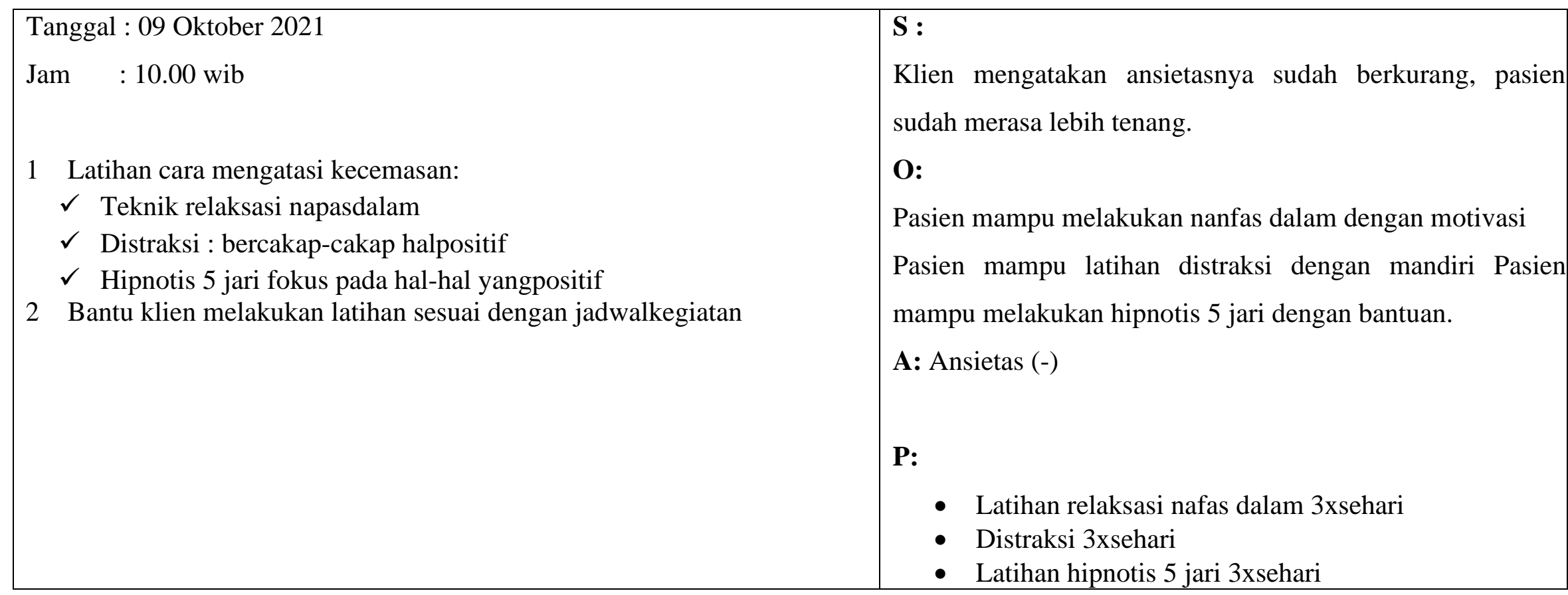




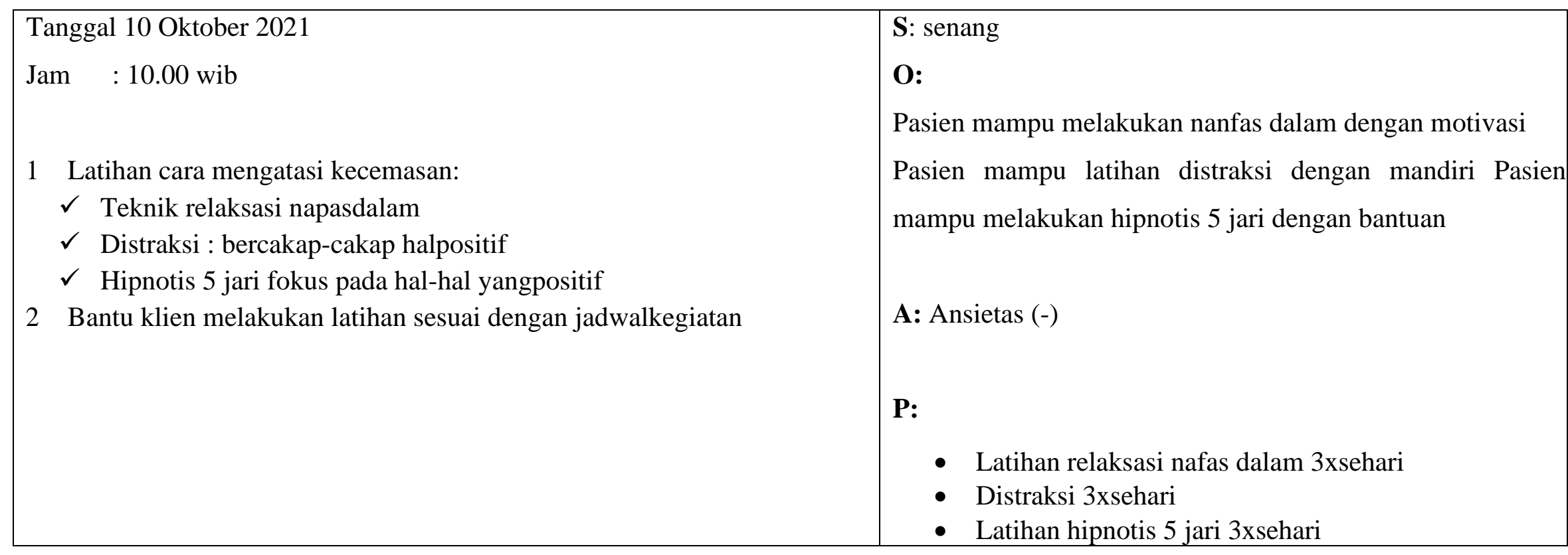




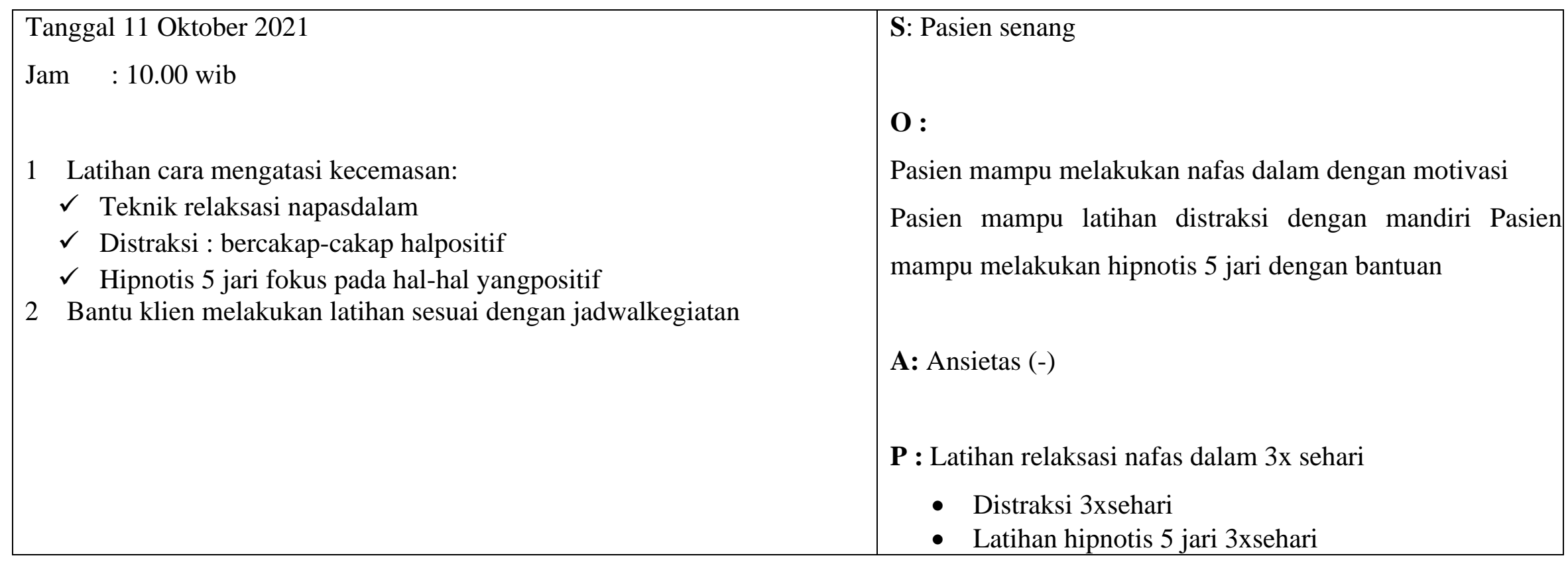




\section{BAB 4}

\section{PEMBAHASAN}

Setelah penulis melaksanakan asuhan keperawatan kepada Tn. A dengan Kecemasan di lingkungan Bakti Luhur Medan Helvetia maka penulis pada BAB ini akan membahasan kesenjangan antara teoritis dengan tinjauan kasus. Pembahasan dimulai melalui tahapan proses keperawatan yaitu pengkajian, diagnosa keperawatan, perencanaan, pelaksanaan dan evaluasi.

\subsection{Tahap Pengkajian}

Selama pengkajian dilakukan pengumpulan data dari beberapa sumber, yaitu dari pasien dan tetangga sekitar. Maka penulis melakukan pendekatan kepada pasien melalui komunikasi teraupetik yang lebih terbuka membantu klien untuk memecahkan perasaannya dan juga melakukan observasi kepada pasien. Adapun upaya tersebut yaitu :

1. Melakukan pendekatan dan membina hubungan saling percaya diri pada klien agar klien lebih terbuka dan lebih percaya dengan menggunakanperasaan.

2. Mengadakan pengkajian klien dengan wawancara dalam pengkajian ini, penulis tidak menemukan kesenjangan karena ditemukan hal sama seperti: diteori: Kecemasan adalah keadaan emosi dan pengalaman subyektif individu, tanpa objek yang spesifik karena ketidaktahuan dan mendahului pengalamanya yang baru seperti penyakitnya saatini

\subsection{Tahap Perencanaan}

Perencanaan dalam proses keperawatan lebih dikenal dengan rencana asuhan keperawatan yang merupakan tahap selanjutnya setelah pangkajian dan penentuan diagnosa keperawatan. Pada tahap perencanaan penulis hanya menyusun rencana tindakan keperawatan sesuai dengan pohon masalah keperawatan yaitu :Kecemasan. Pada tahap ini antara tinjauan teoritis dan tinjaun kasus tidak ada kesenjangan sehingga penulis dapatmelaksanakan tindakan seoptimal mungkin dandidukung dengan 
seringnya bimbingan dengan pembimbing. Secara teoritis digunakan cara strategi pertemuan sesuai dengan diagnosa keperawatan yang muncul saat pengkajian. Adapun upaya yang dilakukan penulis yaitu :

1. Klien mengungkapkan ketidakpastian tentang fluktuasi tingkat energi dan bersikappasif.

2. Klien menunjukan sikap apatis, depresi terhadap perburukan fisik yang terjadi dengan mengabaikan kepatuhan pasien terhadap program pengobatan

3. Klien mengalami ketergantungan pada orang lain yang dapat mengakibatkan ititabilitas, ketidaksukaan, marah dan rasa bersalah. Klien tidak melakukan praktik perawatan diri ketika ditantang. Klien tidak ikut memantau kemajuan pengobatan. Klien menunjukan ekspresi ketidakpuasan terhadap ketidakmampuan melakukan aktivitas atau tugas sebelumnya. Klien menunjukan ekspresi keraguan tantang performa peran.

\subsection{Tahap Implementasi}

Pada tahap implementasi, penulis hanya mengatasi 1 masalah keperawatan yakni: diagnosa keperawatan Kecemasan merupakan keadaan emosi dan pengalaman subyektif induvidu, tanpa objek spesifik karena ketidaktahuan dan mendahului semua pengalaman yang di alami penyakit Hipertensi

\subsection{Tahap Evaluasi}

Pada tinjauan teoritis evaluasi yang diharapkan adalah:

1. Membina hubungansalingpercaya

2. Mengenali danmengekspresikanemosinya

3. Mampu mengenalansietas

4. Mampu mengatasi ansietas melalui teknikreleksasi

5. Mampu mengatasi ansietas dengandistraksi

6. Mampu mengatasi ansietas melalui hipnotis limajari 


\section{BAB 5}

\section{PENUTUP}

\subsection{Kesimpulan}

Berdasarkan uraian pada pembahasan diatas, maka penulis dapat disimpulkan bahwa:

1. Pengkajian dilakukan secara langsung pada klien dan juga dengan menjadikan status klien sebagai sumber informasi yang dapat mendukung data-data pengkajian. Selama proses pengkajian, perawat mengunakan komunikasi terapeutik serta membina hubungan saling percaya antara perawat-klien. Pada kasus Kecemasan :Hipertensi

2. Diagnosa keperawatan yang utama pada klien dengan Kecemasan: Hipertensi

3. Perencanaan dan implementasi keperawatan disesuaikan dengan strategi pertemuan padapasien.

4. Evaluasi keperawatan yang dilakukan menggunakan metode subyektif, obyektif, assessment danplaning.

\subsection{Saran}

1. Untuk institusi pendidikan

Diharapkan lebih meningkatkan pelayanan pendidikan yang lebih tinggi dan menghasilkan tenaga kesehatan yang profesional berwawasan global

2. Untuk keluarga

Diharapkan agar individu dan keluarga bisa mengerti tentang penyakit hipertensi, dan meningkatkan perilaku hidup sehat dengan tujuan meningkatkan kualitas hidup. 


\section{DAFTAR PUSTAKA}

1. Andrian Patica N. (E-journal keperawatan volume 4 nomor 1 Mei 2016). Hubungan Konsumsi Makanan dan Kejadian Hipertensi pada Lansia di Puskesmas Ranomut KotaManado

2. Pardede, J. A. (2020). Konsep Ketidakberdayaan.

3. Pardede, J. A. (2020). Terapi Keluarga.

4. Hulu, E. K., \& Pardede, J. A. (2016). Dukungan Keluarga Dengan Tingkat Kecemasan Pasien Pre Operatif Di Rumah Sakit Sari Mutiara Medan. Jurnal Keperawatan, 2(1),12.

5. Kadir, A. (2018). Hubungan patofisiologi hipertensi dan hipertensi renal. Jurnal Ilmiah Kedokteran Wijaya Kusuma, 5(1), 15-25.

6. Kaplan, MN., 2016. Kaplan's Clinical Hypertension. 9 thed. USA : Lippincott Williams \& Wilkins. Lancet ; 358 : 1682-1686.

7. Keliat, B.A., Hamid, A.Y.S., Putri, Y.S.E. (2019). Asuhan Keperawatan Jiwa. Jakarta:EGC

8. Kemenkes RI, 2016. Pedoman Teknis Penemuan Dan Tatalaksana Hipertensi. Jakarta

9. Marbun, A., Pardede, J. A., \& Perkasa, S. I. (2019). Efektivitas Terapi Hipnotis Lima Jari terhadap Kecemasan Ibu Pre Partum di Klinik Chelsea Husada Tanjung Beringin Kabupaten Serdang Bedagai. Jurnal Keperawatan Priority, 2(2), 92-99. https://doi.org/10.34012/jukep.v2i2.568

10. Pardede, J. A. (2020). Standar Asuhan Keperawatan Jiwa Dengan Masalah Kecemasan.

11. Pardede, J. A., Sitepu, S. F. A., \& Saragih, M. (2018). The Influence of Deep Breath Relaxation Techniques and Five-Finger Hypnotic Therapy on Preoperative Patient Anxiety. Journal of Psychiatry, 3(1),1-8.

12. Pardede, J. A., Simanjuntak, G. V., \& Waruwu, J. F. A. P. (2020). Penurunan Tingkat Kecemasan Pasien HIV/AIDS melalui Terapi Hipnotis Lima Jari. Coping: Community of Publishing in Nursing, 8,85-90.

13. Pardede, J. A., \& Simangunsong, M. M. (2020). Family Support With The Level of Preschool Children Anxiety in the Intravenous Installation. Jurnal Keperawatan Jiwa (JKJ): Persatuan Perawat Nasional Indonesia, 8(3),223-234.

14. Pardede, J. A. (2021). Standar Asuhan Keperawatan Dengan Kesiapan Peningkatan Pengetahuan.

15. Pardede, J. A., Eli, D. S. P. H., \& Sirait, A. (2021). Tingkat Kecemasan Menurun Setelah Diberikan Terapi Hipnotis Lima Jari Pada Pasien Preoperatif. Jurnal Keperawatan, 13(1),265-271.

16. Pardede, J., Simanjuntak, G. V., \& Manalu, N. (2020). Effectiveness of deep breath relaxation and lavender aromatherapy against preoperative patient anxiety. Diversity and Equality in Health and Care, 17(4), 168- 173.

17. Setyaningsih, R. D. (2015). Studi Prevalensi Dan Kajian Faktor Risiko Hipertensi Pada Lansia Di Desa Tambaksari - Banyumas. Prosiding Seminar Nasional \& Internasional,1-6.

18. Setyawan, A., \& Hasnah, K. (2020). Efektivitas Wet Cupping Therapy Terhadap Kecemasan Pada Pasien Hipertensi. Jurnal Kesehatan Kusuma 
Husada, 212-217.https://doi.org/10.34035/jk.v11i2.574

19. Stuart, G. W. (2019). Buku saku keperawatan jiwa.

20. Triyanto,E. 2014. Pelayanan Keperawatan Bagi Penderita Hipertensi secara terpadu,GrahaIlmu.Jakarta.

21. Wau, E. T., Pardede, J. A., \& Simamora, M. (2018). Levels of Stress Related to Incidence of Gastritis in Adolescents. Mental Health, 4(2).

22. WHO (2011) 'Global status report on noncommunicable diseases 2010', World Health Organization, p.176.

23. Yogiantoro,E.,2007.Buku Ajar Ilmu Penyakit Dalam Jilid I. Departemen Ilmu Penyakit Dalam FKUI. JakartaPusat.

24. Zahara, F. (2017). Hubungan antara kecemasan dengan tekanan darah pada Penderita hipertensi di rsu pku muhammadiyah yogyakarta. Kognisi Jurnal, Vol.2 No.1 Agustus 2017 2528-4495, 2(1),42-53. 